\title{
Production of islet cell antibodies from Epstein-Barr virus-transformed peripheral blood lymphocytes in Type 1 (insulin-dependent) diabetic patients
}

\author{
Y. Yamaguchi, N. Chikuba, T. Nakanishi, H. Yamamoto, S. Okuno, Y. Maeda, M. Akashi, S. Akazawa and S. Nagataki \\ The First Department of Internal Medicine, Nagasaki University School of Medicine, Nagasaki, Japan
}

Summary. Islet cell antibodies are usually detected in the sera of almost all Type 1 (insulin-dependent) diabetic patients within several months after onset of the disease. The antibodies then disappear quite early during the course of the disease. The present study was undertaken to detect islet cell antibody-producing clones in peripheral blood lymphocytes of Type 1 diabetic patients whose islet cell antibodies could not be detected in sera. Epstein-Barr virus-transformed lymphocytes were employed to enhance the production of antibodies and to detect the clones from peripheral blood lymphocytes. Peripheral blood lymphocytes were obtained from 40 islet cell antibody-negative Type 1 diabetic patients, 10 antibody-positive Type 1 diabetic patients, 30 Type 2 (non-insulin-dependent) diabetic patients and 40 normal control subjects. Epstein-Barr virus-transformed lymphocytes were cultured for 4 weeks and the culture supernatants were used for assay of islet cell antibodies. Islet cell antibody assays were performed by immunohistochemical methods using peroxidase-labelled protein A for $\mathrm{IgG}$ antibodies, peroxidase-labelled anti-human IgM antibodies for IgM anti- bodies and fresh frozen human pancreatic tissue. IgG-islet cell antibodies were detected in 26 islet cell antibody-negative patients $(65 \%)$, eight antibody-positive patients $(80 \%)$ and one Type 2 diabetic patient (3\%) in the culture supernatants. Islet cell antibodies in the supernatants could not be detected in any of the control subjects. IgM-islet cell antibodies could not be detected in any of the patients or control subjects. These findings indicate that islet cell antibody-producing clones exist in peripheral blood lymphocytes from Type 1 diabetic patients whose islet cell antibodies cannot be detected in their sera and IgG-islet cell antibodies might be a specific characteristic of Type 1 diabetes. The detection of islet cell antibodies from Epstein-Barr virus-transformed lymphocytes may be useful in examining the role of autoimmune mechanisms in the development of disease.

Key words: Islet cell antibodies, Type 1 (insulin-dependent) diabetes, Epstein-Barr virus, peripheral blood lymphocytes, transformation.
A great deal of evidence has been accumulated concerning the aetiological roles of both humoral and cell-mediated immunity in Type 1 (insulin-dependent) diabetes. Islet cell antibodies (ICA) were initially found in diabetes mellitus associated with polyendocrine disease [1]. ICA were present in almost all Type 1 diabetic patients within several months of diagnosis [2-6]. However, ICA usually rapidly disappear and are often impossible to detect in Type 1 diabetic patients after several years of disease duration. We recently reported a new method of detecting ICA in sera using peroxidase-labelled protein A (POPA) and fresh frozen human pancreatic tissue [7]. Using this method, ICA were detected in $100 \%$ of the Japanese Type 1 diabetic patients studied within 6 months of disease onset. However, the prevalence of ICA declined with increasing duration of the disease, similar to the findings in other reports $[3,4]$. Therefore, ICA are not always use- ful as a serum marker for Type 1 diabetes. However, Epstein-Barr virus (EBV) transformation and hybridoma technology have been used to enhance production of antibodies and to prepare monoclonal antibody-producing cell lines $[8,9]$. Therefore, the present study was undertaken to investigate the usefulness of EBV transformation for detecting ICA-producing clones from peripheral blood lymphocytes (PBL) in ICA-negative Type 1 diabetic patients and to determine the clinical significance of detecting ICA-producing clones in these patients.

\section{Subjects and methods}

\section{Subjects}

The group studied included 50 Type 1 diabetic patients and 30 Type 2 (non-insulin-dependent) diabetic patients who were classified according to the classification of the National Diabetes 
Data Group [10]. All the patients were admitted and followed-up in our clinic from 1983 to 1989 . Among the 50 Type 1 diabetic patients (16 males, 34 females), 10 were ICA-positive (4 male, 6 female) and 40 were ICA-negative (12 male, 28 female). The ages of onset, duration of diabetes and insulin requirement in the ICA-positive and negative Type 1 diabetic patients were not significantly different; $20.8 \pm 8.6$ vs $23.4 \pm 11.6$ years, $10.9 \pm 9.1$ vs $12.3 \pm 8.5$ years and $0.69 \pm 0.38$ vs $0.63 \pm 0.22 \cdot \mathrm{U} \mathrm{kg}^{-1} \cdot \mathrm{day}^{-1}$, respectively. Thirty Type 2 diabetic patients (15 male, 15 female) who were diabetic on oral glucose tolerance testing but did not require insulin treatment for blood glucose control, were also selected. The age at onset and duration of diabetes were $47.9 \pm 14.1$ and $8.2 \pm 5.1$, respectively. Forty control subjects ( 28 male, 12 female), whose ages were $31.5 \pm 6.7$ years, were selected based on a normal oral glucose tolerance test result, normal levels of $\mathrm{HbA}_{1}$, no history of glucosuria, hyperglycaemia and no family history of diabetes.

\section{Methods}

Heparinized venous blood was obtained from 40 ICA-negative Type 1 diabetic patients, 10 ICA-positive Type 1 diabetic patients, 30 ICA-negative Type 2 diabetic patients and 40 ICA-negative normal control subjects. Peripheral blood lymphocytes were isolated from $20 \mathrm{ml}$ of heparinized whole venous blood by Ficoll-Conray (specific gravity; 1078) density-gradient centrifugation. They were washed with phosphate buffered saline (PBS) (10 mmol/1, pH 7.4) and resuspended in RPMI 1640 (Gibco, Grand Island NY., USA) containing $10 \%$ fetal bovine serum (FBS) (Gibco). EBV was isolated from the culture supernatants of $B 95-8$ marmoset cell lines [8]. B95-8 cells suspended at a concentration of $5 \times 10^{5}$ cells $/ 1.0 \mathrm{ml}$ of RPMI 1640 containing $15 \%$ FBS were cultured for 7 days at $37^{\circ} \mathrm{C}$ in $5 \% \mathrm{CO}_{2}$ and $95 \%$ air. EBV-containing supernatants were removed, passed through a $0.45 \mu \mathrm{m}$ membrane filter (Millipore Corp., Bedford, Mass., USA), and stored at $-80^{\circ} \mathrm{C}$ as virus stocks. $1 \times 10^{6}$ peripheral blood lymphocytes were suspended in $1 \mathrm{ml}$ of RPMI 1640 containing $15 \%$ FBS, mixed with $1 \mathrm{ml}$ of the stocked B95-8 cell line supernatants, incubated for $2 \mathrm{~h}$ at $37^{\circ} \mathrm{C}$ in $5 \% \mathrm{CO}_{2}$ and $95 \%$ air and washed once with culture medium. The infected $1 \times 10^{6}$ peripheral blood lymphocytes were resuspended in $1 \mathrm{ml}$ of fresh RPMI 1640 containing $10 \%$ FBS and antibiotics (penicillin and streptomycin) and seeded in 24-well plates (3424 MARK II; Costar, Cambridge, Mass., USA). On the third day, $1 \mathrm{ml}$ of fresh culture media was added to each well. The occurrence of cell transformation was judged by cell aggregation, acid production and increase of cell number [8]. Half of the culture media was changed and stocked two or three times per week for at least 4 weeks.

The gamma-globulin fractions in the supernatants of EBV-transformed lymphocytes were precipitated by saturated ammonium sulphate and dialyzed against distilled water. After dialysis, the solutions were lyophilized by Speed Vac Concentrator (Savant Instrument, Inc., NY., USA) before performing ICA assays. The lyophilized samples were dissolved with distilled water (one hundredth of their initial supernatant volumes). IgG-ICA were detected by immunohistochemical staining with peroxidase-labelled protein A (POPA) [7]. The staining procedure by POPA is as follows; fresh frozen sections of human pancreatic tissue (blood type 0 ) were washed three times with PBS ( $10 \mathrm{mmol} / \mathrm{l}, \mathrm{pH} 7.2)$ containing $2 \%$ bovine serum albumin (BSA) (RIA grade; Sigma., St. Louis, MO., USA). Fifty $\mu$ l of sample was applied to the pancreatic tissue and incubated in a moist chamber for $1 \mathrm{~h}$ at room temperature. The tissue was washed three times with excess PBS. POPA was prepared by our laboratory as follows: free protein A (Pharmacia, Uppsala, Sweden) was conjugated with horse radish peroxidase (Sigma) and chromatography was carried out to allow separation into POPA and nonbound peroxidase. Fifty $\mu$ l of POPA $(20 \mu \mathrm{g} / \mathrm{ml})$ was applied and incubated for $30 \mathrm{~min}$. After washing the tissues with PBS three times, samples were allowed to react with Karnovsky's diaminobenzidine solution [11] for $8 \mathrm{~min}$ at room temperature. Slides were mounted and observed under light microscopy. Positive staining could be determined by cytoplasmic staining of islet cells. It has been shown that by using this method, anti-nuclear, anti-microsomal and anti-mitochondrial antibodies do not interfere with the detection of ICA [7]. IgM-ICA in the culture supernatants were also assayed by using peroxidase-labelled anti-human IgM antibodies (Cappel, Malvern, PA., USA). The staining procedures were the same as those of POPA for IgG-ICA. The sensitivity, specificity and reproducibility of our assay for ICA were $88 \%, 100 \%$ and $95 \%$, respectively. The levels of ICA were expressed in IDF (Juvenile Diabetes Foundation) units by using the world standard ICA positive sera [12]. The JDF units of each sample were computed by comparing the endpoints of dilution of the standard sera and samples. IgG in the culture supernatants of EBV-transformed PBL was measured by a two-step solid phase radioimmunoassay. The procedure is as follows: 96-well polystyrene plates (U-bottom; Falcon., Becton Dickinson Lab., Oxnard, CA., USA) were coated with $50 \mu \mathrm{l}$ of rabbit anti-human IgG $(1 \mathrm{mg} / \mathrm{ml})$ prepared in our laboratory. The plates were washed with phosphate buffer (100 mmol/l, pH 7.2) containing 1\% BSA and $40 \mu \mathrm{l}$ of culture media was applied. The plates were then incubated for $1 \mathrm{~h}$ at room temperature. The plates were then washed with phosphate buffer without BSA three times and $40 \mu$ of ${ }^{125}$ I-labelled sheep anti-human $\operatorname{IgGF}(\mathrm{ab})_{2}$ fragment antibody $(20000 \mathrm{cpm} / 40 \mu \mathrm{l})$ (Amersham, Arlington Heights, Ill., USA) were added and the plates were again incubated for exactly $1 \mathrm{~h}$ at room temperature. They were then washed three times with phosphate buffer, dried, and cut with a hot wire cutter and counted in a gamma counter. The assay range of $\mathrm{IgG}$ was $18 \mathrm{ng} / \mathrm{ml}$ to $10.0 \mu \mathrm{g} / \mathrm{ml}$.

\section{Statistical analysis}

Chi-analysis and Wilcoxon's $t$-test were used to statistically analyse our data. The values were expressed as mean $\pm \mathrm{SD}$. $p$-values were derived from the standard table and a 0.05 level of probability was used as the criterion for significance.

\section{Results}

The levels of $\mathrm{IgG}$ in the supernatants of EBV-transformed peripheral blood lymphocytes are shown in Table 1 . IgG gradually increased from the 10th day and reached its maximum in the 4th week for all groups. There was no significant difference in the levels of IgG among the four groups. Figure 1 shows staining of pancreatic tissues using POPA. Figures 1-A and 1-B show positive and negative staining, respectively, when ICA positive (80 JDF units) and negative sera were used as the controls for the assay. The cystoplasm of the islet cells were clearly stained as shown in Figure 1-A. The pattern of staining in ICA posi-

Table 1. Levels of IgG in the supernatants from Epstein-Barr virus transformed peripheral blood lymphocytes

\begin{tabular}{lllll}
\hline Days & 0 & 10 & 20 & 30 \\
\hline $\begin{array}{l}\text { ICA }(+) \text { Type 1 diabetic } \\
\text { patients }(n=10)\end{array}$ & 0 & $0.8 \pm 0.2$ & $1.6 \pm 0.4$ & $3.7 \pm 0.3$ \\
$\begin{array}{l}\text { ICA }(-) \text { Type 1 diabetic } \\
\text { patients }(n=40)\end{array}$ & 0 & $0.9 \pm 0.3$ & $1.5 \pm 0.2$ & $3.9 \pm 0.2$ \\
$\begin{array}{l}\text { Type 2 diabetic } \\
\text { patients }(n=30)\end{array}$ & 0 & $0.7 \pm 0.2$ & $1.7 \pm 0.3$ & $4.1 \pm 0.2$ \\
$\begin{array}{c}\text { Control subjects } \\
(n=40)\end{array}$ & 0 & $0.6 \pm 0.3$ & $1.6 \pm 0.6$ & $3.8 \pm 0.3$ \\
\hline
\end{tabular}

ICA: Islet cell antibodies

Values are means \pm SD $(\mu \mathrm{g} / \mathrm{ml})$ 


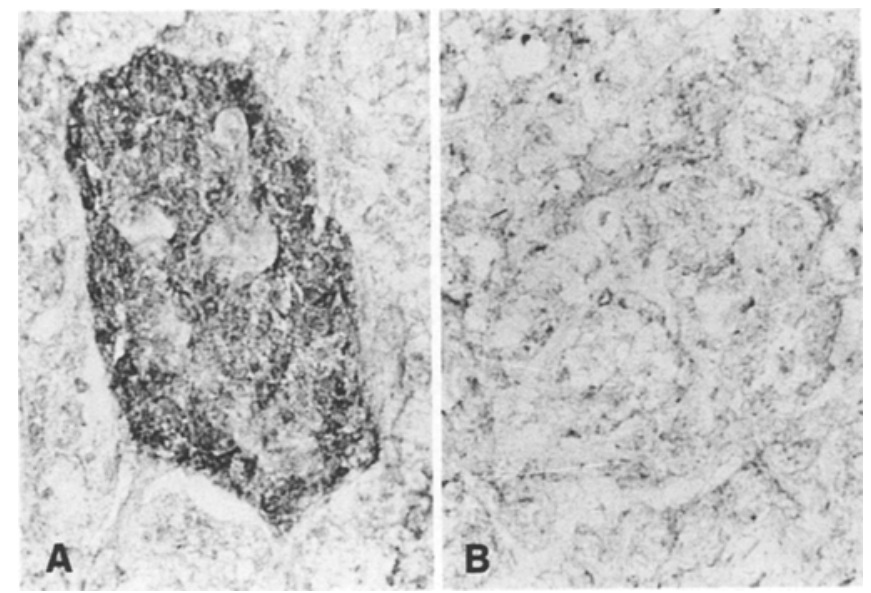

Fig. 1 A,B. Assay of islet cell antibodies (ICA) by peroxidase-labelled protein A (POPA) using standard positive and negative sera. A shows positive and $\mathbf{B}$ negative staining, respectively. The tissues were human pancreatic tissue obtained during surgery from a 53year-old patient with gastric cancer. Positive control sera was obtained from a 30-year-old Type 1 (insulin-dependent) diabetic patient with a titre of $80 \mathrm{JDF}$ units. Negative control sera was from a 33 -year-old healthy male subject. Magnification is $\times 250$

tive supernatant was not different from that seen with ICA-positive sera. The detection of ICA in the supernatants of EBV-transformed PBL from all subjects is summarised in Table 2. IgG-ICA were detected in eight of ICA positive Type 1 diabetic patients (80\%), 26 of ICA negative Type 1 diabetic patients $(65 \%)$ and one of 30 Type 2 diabetic patients ( $3 \%$ ). ICA could not be detected in any of the control subjects. On the other hand, IgM-ICA in the supernatant were not detected in any of the patients or control subjects. The levels of ICA in the sera and concentrated supernatants from ICA-positive Type 1 diabetic patients were $37.5 \pm 35.7$ (range 2.5-80) and $2.5 \pm 0.0$ (all were 2.5) JDF units, respectively. There was no correlation between the titres in sera and culture supernatants. In the rate of detection of ICA, there was a significant difference between the ICA negative Type 1 diabetic patients and Type 2 diabetic patients $(p<0.001)$. There was also a significant difference between the ICA-negative Type 1 diabetic patients and the control group $(p<0.001)$. However, there was no significant difference between ICA positive and negative Type 1 diabetic patients. In the levels of ICA from the concentrated supernatants, the titres from ICA-positive supernatants were all 2.5 JDF units and there was no significant difference between ICA-positive and negative Type 1 diabetic patients.

\section{Discussion}

In the present study, it was demonstrated that ICA-producing clones exist in peripheral blood lymphocytes of Type 1 diabetic patients whose ICA cannot be detected in sera. Furthermore, it was suggested that the presence of ICA-producing clones was significantly specific for Type 1 diabetes because the ICA-producing clones could only be detected in one of the Type 2 diabetic patients and none among normal control subjects. It was recently reported that EBV-transformed lymphocytes from Type 1 diabetic patients could produce $\operatorname{Ig} G$ antibodies to insulin to a much greater extent than control subjects [13]. Furthermore, the production of IgM antibodies to insulin did not differ between Type 1 diabetic patients and control subjects in their reports. In our study, IgM-ICA could not be detected in the supernatants of the patients or the control subjects. From these results, it was suggested that IgG-ICA might be an especially specific characteristic of Type 1 diabetes mellitus.

It was shown in earlier reports that anti-thyroid autoantibodies and anti-acetylcholine receptor antibodies were produced in vitro from peripheral blood lymphocytes in normal subjects [14-16]. However, ICA could not be detected in the culture supernatants of Type 2 diabetic patients and normal control subjects in spite of using EBV transformation which non-specifically enhances the production of autoantibodies. From these findings, it was concluded that there might be a difference in the specificities of autoantibodies to the disease between Type 1 diabetes and the other autoimmune diseases.

The detection of ICA-producing clones may therefore be beneficial for differentiating Type 1 diabetes from Type 2 diabetes. It could be useful in the diagnosis of Type 1 diabetes in patients in whom the clinical course is atypical; i.e. where the age of onset of diabetes is more than 30 years and ICA is negative but C-peptide is undetectable. However, ICA-producing clones were not detected in 14 of 40 ICA-negative Type 1 diabetic patients and in two of ten ICA-positive patients. In two of ten ICApositive patients whose results were ICA-negative in vitro, the procedures of EBV were repeated at least three times. However, ICA could not be detected in the culture supernatants at any time. Since only $10 \mathrm{ml}$ of blood samples were employed in the present study, it is likely that ICAproducing clones were not included in the transformed $\mathrm{B}$-lymphocytes which are relatively scarce in peripheral blood lymphocytes. The reason why ICA-negative Type 1 diabetic patients developed ICA-positive culture supernatants following EBV transformation is not clear. There are some possible explanations. It is well-known that polyclonal immunoglobulin productions can be induced by EBV transformation and be independent of Tlymphocytes [17]. On the other hand, T lymphocytes have important

Table 2. The detection of islet cell antibodies (ICA) in the supernatants of Epstein-Barr virus - transformed peripheral blood lymphocytes

\begin{tabular}{|c|c|c|c|c|}
\hline & & serum-ICA & $\begin{array}{l}\text { IgG-ICA } \\
\text { (titre) }^{a}\end{array}$ & $\begin{array}{l}\text { IgM-ICA } \\
\text { (titre) }\end{array}$ \\
\hline $\begin{array}{l}\text { ICA(+) Type } 1 \\
\text { diabetic patients }\end{array}$ & $(n=10)$ & $\begin{array}{l}2.5-80 \\
(37.5 \pm 35.7)\end{array}$ & $\begin{array}{l}8 / 10 \\
(2.5 \pm 0.0)^{b}\end{array}$ & $0 / 10$ \\
\hline $\begin{array}{l}\text { ICA }(-) \text { Type } 1 \\
\text { diabetic patients }\end{array}$ & $(n=40)$ & & $\begin{array}{l}26 / 40 \\
(2.5 \pm 0.0)^{\mathrm{b}}\end{array}$ & $0 / 40$ \\
\hline $\begin{array}{l}\text { Type } 2 \text { diabetic } \\
\text { patients }\end{array}$ & $(n=30)$ & & $1 / 30(2.5)$ & $0 / 30$ \\
\hline Control subjects & $(n=40)$ & & $0 / 40$ & $0 / 40$ \\
\hline
\end{tabular}

${ }^{a}$ Titres in the concentrated culture media; ${ }^{\circ}$ Significant difference from Type 2 and control subjects 
roles in the production of antibodies in vivo. Therefore, it is suggested that EBV might activate ICA-producing $B$ lymphocytes which are suppressed by $T$ lymphocytes in vivo and induce the production of ICA in vitro from transformed B lymphocytes. It is certainly important that the enrichment of ICA-producing clones in the blood samples may partially decide the rate of detection of ICA in the present study.

In summary, it was shown that ICA-producing clones exist in ICA-negative Type 1 diabetic patients. The data indicated that EBV transformation may be useful in detecting ICA-producing clones from peripheral blood lymphocytes and therefore differentiate Type 1 from Type 2 diabetic patients. Especially, IgG-ICA are thought to be a specific characteristic of Type 1 diabetes. However, several factors may be necessary in the future to differentiate the two groups clearly, e.g., improvement in the sensitivity and specificity of the ICA assays, cloning of a specific antigen to ICA, analysis using molecular biology, etc. Furthermore, progress in the immunogenetic field will be necessary to elucidate the pathogenesis of Type 1 diabetes.

Acknowledgements. We thank Ms. M. Takase for excellent technical assistance. We appreciate the secretarial help of Ms. C. Tsuruta and Ms. Y.Takahara and Dr. L.F.Kumagai, University of California, Davis for his suggestions and editing of manuscript.

\section{References}

1. Bottazzo GF, Florin-Christensen A, Doniach D (1974) Islet-cell antibodies in diabetes mellitus with autoimmune polyendocrine deficiency. Lancet II: 1279-1282

2. Lendrum R, Walker G, Cudworth AG, Theophanides C, Pyke DA, Bloom A, Gamble DR (1976) Islet-cell antibodies in diabetes mellitus. Lancet I: 1273-1276

3. Bruining GJ, Molenaer J, Tuk CW, Lindeman J, Bruining HA, Marner B (1984) Clinical time-course and characteristics of islet cell cytoplasmic antibodies in childhood diabetes. Diabetologia 26: $24-29$

4. Irvine WJ, McCallum CJ, Gray RS, Campbell CJ, Duncan LJP, Farquhar JW, Vaugham H, Morris PJ (1977) Pancreatic islet-cell antibodies in diabetes mellitus correlated with the duration and type of diabetes, coexistent autoimmune disease and HLA. Diabetes 26: 138-147

5. Bottazzo GF, Doniach D, Pouplard A (1976) Humoral autoimmunity in diabetes mellitus. Acta Endocrinol [Suppl 205] 83: 5361
6. Del Prete GF, Betterle C, Padovan D, Erle G, Toffolo A, Bersahi $\mathrm{G}$ (1977) Incidence and significance of islet-cell autoantibodies in different types of diabetes mellitus. Diabetes 26: 909-915

7. Takahashi A, Tsujihata M, Yokota A, Yamaguchi Y, Ueda Y, Akazawa S, Miyake S, Nagataki S (1986) A new method of detection of islet cell antibodies (ICA) using peroxidase-labelled protein $A$, and incidence of ICA in Type 1 (insulin-dependent) diabetes. Diabetologia 29:378-382

8. Miller G, Lipman M (1973) Release of infectious Epstein-Barr virus by transformed marmocet leukocytes. Proc Natl Acad Sci USA 70: 190-194

9. Prabhakar BS, Saegusa J, Onodera T, Notkins AL (1984) Lymphocytes capable of making monoclonal autoantibodies that react with multiple organs are a common feature of the normal B cell repertoire. J Immunol 133:2815-2817

10. National Diabetes Data Group (1979) Classification and diagnosis of diabetes mellitus and other categories of glucose intolerance. Diabetes 28: 1039-1057

11. Karnovsky MZ (1967) The ultrastructural basis of capillary permeability studied with a peroxidase tracer. I Cell Biol 35:213-236

12. Boitard C, Bonifacio G, Bottazzo GF, Gleichmann H, Molenaar $J$ (1988) Immunology and Diabetes Workshop: Report on the Third International (Stage 3) Workshop on the Standardization. of Cytoplasmic Islet Cell Antibodies. Diabetologia 31: 451-452

13. Casali P, Nakamura M, Ginsberg-Feller F, Notkins AL (1990) Frequency of $B$ cells committed to the production of antibodies to insulin in newly diagnosed patients with insulin-dependent diabetes mellitus and generation of high affinity human monoclonal IgG to insulin. J Immunol 144: 683-688

14. Tien-Wen T, Shao-Ling L, Kriss JP (1985) Peripheral blood lymphocytes from normal individuals can be induced to secrete immunoglobulin $\mathrm{G}$ antibodies against self-antigen thyroglobulin in vitro. J Clin Endocrinol Metab 60: 279-282

15. Lisak RP, Larmore C, Levinson AI, Zweiman B, Moskovits AR, White A (1984) In vitro synthesis of antibodies to acetylcholine receptor by peripheral blood cells: role of suppressor T cells in normal subjects. Neurology 34: 802-806

16. Kanazawa H, Eguchi K, Mine M, Ikari N, Kurata A, Fukuda T, Matsunaga M, Nagataki S (1986) Serum from patients with autoimmune diseases induces in vitro production of disease-associated antibodies by peripheral blood mononuclear cells from normal subjects. J Clin Endocrinol Metab 63: 683-688

17. Kirchner H, Tosato G, Blaese RM, Broder S, Magrath I (1979) Polyclonal immunoglobulin section by human B lymphocytes exposed to Epstein-Barr virus. J Immunol 118: 1310-1313

Received: 7 September 1990

and in revised form: 25 March 1991

Dr. Y. Yamaguchi

The First Department of Internal Medicine

Nagasaki University School of Medicine

7-1 Sakamoto-machi

Nagasaki 852

Japan 